Çukurova Üniversitesi Mühendislik Mimarlık Fakültesi Dergisi, 33(1), ss. 189-198, Mart 2018

Çukurova University Journal of the Faculty of Engineering and Architecture, 33(1), pp. 189-198, March 2018

\title{
İş Sağlığı ve Güvenliği Yasal Mevzuatının Türkiye İnşaat Sektöründe Uygulanma Düzeyi
}

\author{
Şahin Tolga GÜVEL ${ }^{* 1}$, Emel LAPTALI ORAL ${ }^{1}$

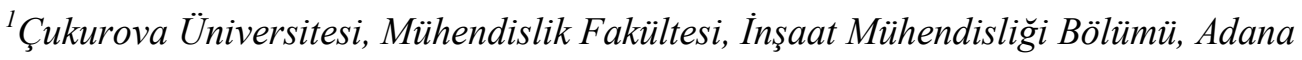

Geliş tarihi: 23.01.2018 Kabul tarihi: 14.03 .2018

$\ddot{\mathbf{O} z}$

İş kazalarının en çok görüldüğü sektörlerden birisi olan inşaat sektöründe iş sağlığı ve güvenliği ile ilgili mevzuatın uygulanmasında sorunlar bulunmaktadır. Bu çalışmada, Türkiye'deki iş kazalarını ve kaza sonucu ortaya çıkabilecek kayıpları en aza indirmek için yapılan yasal düzenlemelerin, inşaat sektöründeki uygulama düzeyi belirlenmeye çalışılmış ve bu kapsamda işçi-usta-formen, teknik personel, yapı denetim personeli, iş güvenliği denetim personeli ve üst düzey yönetici-işveren olmak üzere sektördeki beş farklı meslek grubu çalışanlarına anket uygulanmıştır. Yapılan anket çalışması, literatür bulguları ve yasal mevzuat da göz önüne alınarak değerlendirilmiş ve iş sağlığı ve güvenliği yasal mevzuatının Türkiye inşaat sektöründe uygulanma düzeyi incelenmiştir.

Anahtar Kelimeler: İş sağlığı ve güvenliği, İnşaat sektörü, Yasal mevzuat, İş kazası

\section{Determining The Application Level of Occupational Health and Safety Legislation in Construstion Sector in Turkey}

\begin{abstract}
Application of occupational health and safety legislation is a problematic area for construction sector in which occupational accidents happen most frequently. On this study, the attemp was to determine the application level of occupational health and safety legislation. Therefore, a questionnaire survey was undertaken with five different types of construction employees; workman-foreman, technical staff, building inspection staff, health and safety staff, and top managers. The findings of questionnaires were evaluated considering both the literature findings and related legislation, and the application level of occupational health and safety legislation in construction sector in Turkey was examined.
\end{abstract}

Keywords: Occupational health and safety, Construction sector, Legislation, Work accident

*Sorumlu yazar (Corresponding author): Şahin Tolga GÜVEL, stolgaguvel@yahoo.com 


\section{GíRiş}

Türkiye'de iş sağlığı ve güvenliğinin sağlanması için gerekli yasal düzenlemeler; 6331 Sayılı İş Sağlı̆̆ı ve Güvenliği Kanunu, İş Sağlı̆̆1 ve Güvenliği Yönetmeliği, Yapı İşlerinde İş Sağlığı ve Güvenliği Yönetmeliği, İş Sağlığı ve Güvenliği Hizmetleri Yönetmeliği, Kişisel Koruyucu Donanımların İşyerlerinde Kullanılması Hakkında Yönetmelik, Yapı Müteahhitlerinin Kayıtları ile Şantiye Şefleri ve Yetki Belgeli Ustalar Hakkında Yönetmelik, Çalışanların İş Sağlığı ve Güvenliği Eğitimlerinin Usul ve Esasları Hakkında Yönetmelik ve Geçici veya Belirli Süreli İşlerde İş Sağlığ1 ve Güvenliği Hakkında Yönetmelik ile belirlenmiştir. Bunların dışındaki bazı kanun ve yönetmeliklerde de iş sağlığ ve güvenliği ile ilgili hükümler bulunmaktadır. İş sağlığı ve güvenliği ile ilgili 2012 yılından itibaren peyderpey yürürlüğe girmiş olan yasal mevzuat; uygulanabilmesi durumunda yeterli görünmekle birlikte, yapılan araştırmalar, inşaat sektöründe istenen düzeyde uygulanmadığını göstermektedir. Sektörün kendine has özellikleri ile yasal düzenlemelerin getirdiği kurallara hazır olmaması nedeniyle, tüm sektörler arasında iş kazası açısından en riskli sektörlerden birisi olan inşaat sektörünün, iş sağlığ1 ve güvenliği açısından beklenen seviyeye ulaşması zaman alacaktır.

\section{2. ÖNCEKİ ÇALIŞMALAR}

Yasal mevzuatın uygulanma seviyesini gösteren literatür bulguları aşağıda özetlenerek verilmiştir:

\subsection{Kişisel Koruyucu Donanım (KKD) Kullanımı}

Yapılan araştırmalar incelendiğinde Kişisel Koruyucu Donanım (KKD) kullanım oranı, iş güvenliğine önem verildiği şeklinde değerlendirilmekte ve KKD kullanmayan çalışanlar, iş kazası geçirme yönünden en riskli grup olarak görülmektedir. Dorji ve Hadikusomo [1] tarafindan yapılan bir araştırmaya göre Hong Kong'da KKD kullanım oranları; baret $\% 87,5$; eldiven $\% 80$; gözlük $\% 77,5$; ayakkab1 $\% 70$; yüz koruyucu \%56; emniyet kemeri $\% 50$; solunum maskesi $\% 37,5$; kulak tıkacı $\% 20$ olarak tespit edilmiştir. Kuruoğlu ve arkadaşları [2] tarafından Türkiye'de yapılan bir araştırmada, inşaat işlerinde çalışanların iş güvenliği için baret-eldiven-emniyet kemeri kullanma oranı \% 46, kullanmama oranı $\% 46$ olarak tespit edilmiştir. Çalışanların \%8'inin ise bu konuda fikri bulunmamaktadır. Yapılan diğer bir çalışmada Demirbilek ve Çakır [3] tarafından kişisel koruyucu donanım kullanım oranlar1; Asla kullanmam \%0, Bazen kullanırım $\% 14,7$, Çoğu zaman kullanırım \%28,8, Daima kullanırım \%56,5 olarak tespit edilmiştir.

\subsection{Yetki Belgeli Usta Çalıştırma}

Lam ve Kam [4] tarafindan Hong Kong'da yapılan bir araştırmada, farklı seviyelerde çalışan tüm inşaat işçilerinin davranışının iyileştirilmesi için bir kayıt sistemine dâhil edilmelerinin önemine vurgu yapılmıştır. Yazarlar, çalışmada inşaat sektörü çalışanlarının, inşaat sahasında çalışmadan önce merkezi bir organizasyona kayıt olması ve inşaat işçilerinin meslekleriyle ilgili ruhsatlı bir iş güvenliği eğitimi almaları gerektiğini belirtmişlerdir.

\section{3. İş Güvenliği Eğitimi}

Hassanein ve Hanna [5] tarafindan yapılan bir araştırmanın sonuçlarına göre; firmaların \%20'si, işçilerini resmi olmayan oryantasyon eğitimi ile işe almaktadır. Firmaların \%20'sinin ise, çalışanlarına resmi oryantasyon eğitimi verdiği anlaşılmaktadır. Bunun dışında kalan işçilere hiçbir şekilde oryantasyon eğitimi verilmemiştir. Çalışmanın sonuçlarına göre, firmaların \%20'sindeise, yeni işçilerin oryantasyonundan formenlerin sorumlu olduğu anlaşılmıştır.

Cheng ve arkadaşları [6] tarafindan toplam 800 kaza raporu analiz edilerek yapılan bir çalışmada ise; küçük inşaat firmalarının \%74'ünün iş güvenliği eğitimi vermediği ve bunun sonucu olarak, güvensiz iş yapma alışkanlıklarının arttığı tespit edilmiştir. Metinsoy ve Müngen [7] tarafından yapılan anket çalışmalarının sonuçları da, iş güvenliği eğitimi konusunda büyük bir eksikliğin olduğunu işaret etmektedir. $\mathrm{Bu}$ ve benzeri birçok çalışma, işçilerin çoğunun iş 
güvenliği konusunda detaylı bir eğitiminin olmadığını göstermiştir.

Dikmen ve arkadaşları [8] tarafından iş güvenliği eğitimi konusunda yapılan bir anket çalışmasında ise, şirketlerin \%50'sinin şirket içi eğitimleri periyodik olarak yaptıkları, \%34'ünün ise şirket içi hiçbir eğitim faaliyetinde bulunmadıkları anlaşılmıştır. Şirketlerin \%97'si ise yeni çalışanlarına mutlaka İSG eğitimi verdiklerini belirtmeleri, olumlu bir sonuç olarak çalışmada yer almıştır.

Antmen ve arkadaşları [9] tarafindan şantiye şeflerine yapılan bir anket çalışması ile, katılımcıların \%52,4'ünün iş güvenliği ile ilgili eğitimleri aldıkları, \%47,6'sının ise bu konuda herhangi bir eğitim almadıkları tespit edilmiştir.

Lam ve Kam [4] tarafindan Hong Kong'da yapılan bir yapılan araştırmada ise; inşaat işçilerinin \%61,3'ünün işe başlamadan önce iş güvenliği eğitimi almadıkları saptanmıştır.

\section{4. İş Sağlığı ve Güvenliği Denetimi}

Laitinen ve Ruohomaki [10] tarafindan Finlandiya'da performans yönetimine bağlı bir haftalık denetim yöntemi sonrasında, iki inşaat şantiyesinde denetçi ve çalışanlar tarafından uygulanan iş güvenliği seviyesi gözlemlenmiş ve haftalık iş güvenliği indeksi grafiği çıkartılmıştır. Çalışma sonunda yapılan geri beslemelerle; 1. şantiyede indeks seviyesi \%60'dan \%89'a, 2. şantiyede $\% 67$ 'den \%91'e çıktığ 1 tespit edilmiştir.

Dikmen ve arkadaşları [8] tarafından Türk inşaat sektöründeki uygulamalarla ilgili yapılan araştırmaya göre, projelerin sadece \%42,3'ünün (104 şantiyenin 44'ünün) ISG konusunda resmi makamlar tarafından denetlendiği tespit edilmiştir.

$\mathrm{Bu}$ çalışmanın temel amacı da; Türkiye inşaat sektöründe, yapım işlerinde iş sağlığ 1 ve güvenliği ile ilgili kanun ve yönetmeliklerin uygulanma düzeyini belirlemek ve uygulamada yaşanan sıkıntılar için çözüm önerileri getirmektir. Araştırmada bu amaçla yapılmış olan anket çalışması sonuçları, yasal mevzuat ile birlikte verilerek tartışılmaktadır.

\section{MATERYAL VE METOT}

Türkiye'de yapım işlerinde çalışanlar; işçi-ustaformen, teknik eleman, iş güvenliği denetim elemanı, yap1 denetim elemanı ve üst düzey yöneticiler olarak beș farklı meslek grubuna ayrılmıştır. Önceki çalışmalardan elde edilen veriler ile ilgili yasal mevzuat göz önünde tutularak, iş sağlığ ve güvenliği uygulamalarıyla ilgili görüşlerini belirlemek amacıyla her grup için ayrı olmak üzere; anket soruları hazırlanmıştır. Hazırlanan anketlerin Ocak-Nisan 2013 tarihleri arasında Türkiye genelinde dağıtımı yapılmış ve Temmuz 2013 tarihine kadar toplam 480 adet geri dönüş elde edilmiştir. Geri bildirim alınan anketlerden elde edilen sonuçlar, ilgili yasal mevzuat maddeleri ile birlikte değerlendirilmiştir.

\section{BULGULAR VE TARTIŞMA}

\subsection{Ankete Katılanların Profili}

Ankete katılanların, yapım işlerinde üstlendikleri görev gruplarına göre dağılımları Çizelge 1'de gösterilmektedir. Tabloya göre işçi-usta-formen grubunda 234 kişi $(\% 48,95)$, teknik personel 99 kişi $(\% 20,71)$, yapı denetim personeli 69 kişi $(\% 14,02)$, İSG personeli 30 kişi $(\% 6,28)$ ve üst düzey yönetici-işveren 48 kişi $(\% 10,04)$ olmak üzere toplam 480 inşaat sektörü çalışanı ankete katılmıştır.

Çizelge 1. Anket gruplarının dağılımı

\begin{tabular}{|c|l|c|c|}
\hline $\begin{array}{c}\text { Sıra } \\
\text { No }\end{array}$ & \multicolumn{1}{|c|}{ Anket Grupları } & $\begin{array}{c}\text { Katılımcı } \\
\text { Sayısı }\end{array}$ & $\begin{array}{c}\text { Oranı } \\
(\mathbf{\%})\end{array}$ \\
\hline 1 & İşci-Usta-Formen & 234 & 48,75 \\
\hline 2 & Teknik Personel & 99 & 20,63 \\
\hline 3 & $\begin{array}{l}\text { Yapı Denetim } \\
\text { Personeli }\end{array}$ & 69 & 14,38 \\
\hline 4 & İSG Personeli & 30 & 6,25 \\
\hline 5 & Üst Düzey Yönetici & 48 & 10,00 \\
\hline & TOPLAM & $\mathbf{4 8 0}$ & $\mathbf{1 0 0 , 0 0}$ \\
\hline
\end{tabular}




\subsection{Kişisel Koruyucu Donanım (KKD) Kullanım Oranları}

Yasal mevzuata göre çalş̧anlar KKD kullanmak, işverenler de çalışanlara KKD kullandırmak ile sorumludurlar [11-14]. Yapım işlerinde KKD kullanımı ile ilgili genel teamül; baret ve çelik burunlu ayakkabının inşaat sahası içinde bulunan tüm çalışanlar tarafından kullanılması gerektiği yönündedir. Diğer kişisel koruyucu donanımlar ise, çalışanların yaptıkları işe, iş ve inşaat sahası koşullarına göre yapılacak risk değerlendirmeleri sonucunda belirlenir [13].

Ankete katılanların genel ortalamasına göre; baret kullanımı \%81,10, çelik burunlu ayakkabı kullanımı \%65,49 ve hiç KKD kullanmayanlar $\% 10,95$ oranında tespit edilmiştir (Çizelge 2).

Çizelge 2. Kullanılan kişisel koruyucu donanımlar

\begin{tabular}{|c|l|c|c|c|c|c|c|}
\hline $\begin{array}{c}\text { Sura } \\
\text { No }\end{array}$ & \multicolumn{1}{|c|}{$\begin{array}{c}\text { Şantiyede } \\
\text { Kullanılan KKD }\end{array}$} & $\begin{array}{c}\text { İsçi, Usta, } \\
\text { Formen } \\
\mathbf{( \% )}\end{array}$ & $\begin{array}{c}\text { Teknik } \\
\text { Personel } \\
\mathbf{( \% )}\end{array}$ & $\begin{array}{c}\text { İSG Denetim } \\
\text { Elemanları } \\
\mathbf{( \% )}\end{array}$ & $\begin{array}{c}\text { Yapı Denetim } \\
\text { Elemanlar } \\
\mathbf{( \% )}\end{array}$ & $\begin{array}{c}\text { Üst Düzey } \\
\text { Yönetici- } \\
\text { İsveren } \\
\mathbf{( \% )}\end{array}$ & $\begin{array}{c}\text { Genel } \\
\text { Ortalama } \\
(\%)\end{array}$ \\
\hline 1 & Baret & 67,95 & 89,80 & 96,67 & 57,35 & 93,75 & 81,10 \\
\hline 2 & Çelik Burunlu Ayakkabi & 68,80 & 68,37 & 93,33 & 32,35 & 64,58 & 65,49 \\
\hline 3 & Hiçbiri & 7,26 & 5,10 & 0,00 & 38,24 & 4,17 & 10,95 \\
\hline
\end{tabular}

\subsection{Sağlık Raporları}

Yasal mevzuata göre; inşaat sektörünü de kapsayan, tehlikeli ve çok tehlikeli sınıfta yer alan işlerde çalışacakların, yapacakları işe uygun olduklarını belirten sağlık raporu olmadan işe başlatılmaması gerekmektedir [15].
Anket sonuçları incelendiğinde; genel ortalamaya göre işe başlamadan önce sağlik raporu alma oranının $\% 68,57 \quad$ olduğu görülmektedir (Çizelge 3).

Çizelge 3. İşbaşı öncesi “Ağır ve tehlikeli işlerde çalışabilir” sağlık raporu alma durumu

\begin{tabular}{|c|l|c|c|c|c|c|c|}
\hline $\begin{array}{c}\text { Sıra } \\
\text { No }\end{array}$ & $\begin{array}{c}\text { İşbaşı Öncesi } \\
\text { Ağır ve Tehlikeli } \\
\text { İs Raporu Alma }\end{array}$ & $\begin{array}{c}\text { İşçi, } \\
\text { Usta, } \\
\text { Formen } \\
\mathbf{( \% )}\end{array}$ & $\begin{array}{c}\text { Teknik } \\
\text { Personel } \\
\mathbf{( \% )}\end{array}$ & $\begin{array}{c}\text { ISG } \\
\text { Denetim } \\
\text { Elemanları } \\
\mathbf{( \% )}\end{array}$ & $\begin{array}{c}\text { Yapı } \\
\text { Denetim } \\
\text { Elemanları } \\
\mathbf{( \% )}\end{array}$ & $\begin{array}{c}\text { Üst Düzey } \\
\text { Yönetici - } \\
\text { İşveren } \\
\mathbf{( \% )}\end{array}$ & $\begin{array}{c}\text { Genel } \\
\text { Ortalama } \\
(\mathbf{\% )}\end{array}$ \\
\hline 1 & Evet & 81,12 & 63,64 & 90,00 & 46,38 & 61,70 & 68,57 \\
\hline 2 & Hayır & 11,59 & 33,33 & 3,33 & 42,03 & 34,04 & 24,87 \\
\hline 3 & İşbaş1 Sonrasında & 7,30 & 3,03 & 6,67 & 11,59 & 4,26 & 6,57 \\
\hline
\end{tabular}

\subsection{Yetki Belgeli Usta Çalıştırma}

Yasal mevzuata göre, tehlikeli ve çok tehlikeli sınıfta yer alan işlerde yapacağı işle ilgili mesleki eğitim aldığını belgeleyemeyenler çalıştırılamaz [15]. İnşaat ve tesisat işlerinde, yetki belgeli usta çalıştırılması ve belgelerinin bir örneğini şantiye dosyasında bulundurulması gerekmektedir [16].

Anket sonuçları incelendiğinde; yetki belgesi olmayan ustaların çalıştırılma oranı \% 31,01 olarak tespit edilmiştir (Çizelge 4).

Çizelge 4. Yetki belgeli usta çalıştırma durumu

\begin{tabular}{|c|c|c|c|c|c|c|c|}
\hline Sura No & $\begin{array}{c}\text { Mesleki } \\
\text { Yeterlilik } \\
\text { Belgesi }\end{array}$ & $\begin{array}{c}\text { İşçi, } \\
\text { Usta, } \\
\text { Formen } \\
\mathbf{( \% )}\end{array}$ & $\begin{array}{c}\text { Teknik } \\
\text { Personel } \\
\mathbf{( \% )}\end{array}$ & $\begin{array}{c}\text { ISGG } \\
\text { Denetim } \\
\text { Elemanları } \\
\mathbf{( \% )}\end{array}$ & $\begin{array}{c}\text { Yapı } \\
\text { Denetim } \\
\text { Elemanları } \\
(\%)\end{array}$ & $\begin{array}{c}\text { Üst Düzey } \\
\text { Yönetici - } \\
\text { İşveren } \\
(\%)\end{array}$ & $\begin{array}{c}\text { Genel } \\
\text { Ortalama } \\
(\%)\end{array}$ \\
\hline 1 & Var & 70,83 & 65,96 & 66,67 & 65,38 & 76,09 & 68,99 \\
\hline 2 & Yok & 29,17 & 34,04 & 33,33 & 34,62 & 23,91 & 31,01 \\
\hline
\end{tabular}




\section{5. İş Güvenliği Eğitimleri}

Yasal mevzuata göre çalışanlara; işe başlamadan önce, çalışma yeri veya iş değişikliğinde, iş ekipmanı değiştiğinde, yeni teknoloji uygulandığında ve çok tehlikeli işlerde yılda en az bir defa iş güvenliği eğitimi verilmesinden işveren sorumludur $[11,15,17]$.
Anket genel ortalamasına göre iş güvenliği eğitiminin verilme oranları; işe başlamadan önce $\% 56,29$, çalışma yeri değişikliğinde $\% 18,45$, iş ekipmanı değiştiğinde $\% 13,87$, yılda en az bir defa eğitim \%24,10 olarak tespit edilmiştir (Çizelge 5).

Çizelge 5. Çalıştıkları firmada iş güvenliği eğitimleri verilme zamanı

\begin{tabular}{|c|c|c|c|c|c|c|c|}
\hline $\begin{array}{c}\text { Sira } \\
\text { No }\end{array}$ & $\begin{array}{l}\text { İSG Eğitim } \\
\text { Zamanı }\end{array}$ & $\begin{array}{c}\text { İşçi, } \\
\text { Usta, } \\
\text { Formen } \\
(\%)\end{array}$ & $\begin{array}{c}\text { Teknik } \\
\text { Personel } \\
(\%)\end{array}$ & $\begin{array}{c}\text { ISG } \\
\text { Denetim } \\
\text { Elemanları } \\
(\%) \\
\end{array}$ & $\begin{array}{c}\text { Yapı } \\
\text { Denetim } \\
\text { Elemanları } \\
(\%) \\
\end{array}$ & $\begin{array}{c}\text { Üst Düzey } \\
\text { Yönetici - } \\
\text { İşeren } \\
(\%)\end{array}$ & $\begin{array}{c}\text { Genel } \\
\text { Ortalama } \\
(\%)\end{array}$ \\
\hline 1 & Verilmez & 14,04 & 12,50 & 6,90 & 35,38 & 12,50 & 16,26 \\
\hline 2 & $\begin{array}{l}\text { Yeni Makine } \\
\text { Geldiğinde }\end{array}$ & 13,60 & 10,42 & 24,14 & 10,77 & 10,42 & 13,87 \\
\hline 3 & İşbaş1 Öncesi & 69,30 & 54,17 & 68,97 & 36,92 & 52,08 & 56,29 \\
\hline 4 & İşbaş1 Sonras1 & 7,89 & 9,38 & 20,69 & 7,69 & 6,25 & 10,38 \\
\hline 5 & $\begin{array}{l}\text { Çalışma Yeri } \\
\text { Değişiminde }\end{array}$ & 10,53 & 12,50 & 24,14 & 13,85 & 31,25 & 18,45 \\
\hline 6 & Her 6 Ayda 1 & 10,96 & 22,92 & 24,14 & 10,77 & 22,92 & 18,34 \\
\hline 7 & Her y1lda 1 & 1,75 & 5,21 & 3,45 & 4,62 & 18,75 & 6,76 \\
\hline
\end{tabular}

Ayrıca işveren çalışanlarına, alt işveren çalışanlarına, tam veya kısmi süreli çalışanlara, belirsiz süreli, belirli süreli veya geçici süreli çalışanlara iş güvenliği eğitimi verilmesi işveren sorumluluğundadır $[18,19]$.
Anket genel ortalamasına göre; iş güvenliği eğitimi \%64,99 oranla ana firma çalışanlarına, $\% 55,64$ oranla taşeron çalışanlarına, \%20,56 oranla 30 günden kısa süreli çalışanlara, \%20,32 oranla günlük çalışanlara verilmektedir. Eğitim verilmeme oranı da \%20,06 olarak tespit edilmiştir (Çizelge 6).

Çizelge 6. Çalıştıkları firmada iş güvenliği eğitimi verilenler

\begin{tabular}{|c|c|c|c|c|c|c|c|}
\hline $\begin{array}{c}\text { Sira } \\
\text { No }\end{array}$ & $\begin{array}{c}\text { ISG Eğitimi } \\
\text { Kimlere } \\
\text { Veriliyor }\end{array}$ & $\begin{array}{l}\text { İş̧̧i, } \\
\text { Usta, } \\
\text { Formen } \\
\text { (\%) }\end{array}$ & $\begin{array}{c}\text { Teknik } \\
\text { Personel } \\
(\%)\end{array}$ & $\begin{array}{c}\text { İSG } \\
\text { Denetim } \\
\text { Elemanları } \\
(\%)\end{array}$ & $\begin{array}{c}\text { Yapı } \\
\text { Denetim } \\
\text { Elemanları } \\
(\%)\end{array}$ & $\begin{array}{c}\text { Üst } \\
\text { Düzey } \\
\text { Yönetici - } \\
\text { İşveren } \\
\text { (\%) }\end{array}$ & $\begin{array}{c}\text { Genel } \\
\text { Ortalama } \\
(\%)\end{array}$ \\
\hline 1 & $\begin{array}{l}\text { Ana Firma } \\
\text { Çalışanları }\end{array}$ & - & 69,15 & 83,33 & 29,23 & 78,26 & 64,99 \\
\hline 2 & $\begin{array}{l}\text { Alt İşveren } \\
\text { (Taşeron) } \\
\text { Çalışanları }\end{array}$ & - & 57,45 & 66,67 & 35,38 & 63,04 & 55,64 \\
\hline 3 & $\begin{array}{l}30 \text { Günden Kısa } \\
\text { Çalışanlar }\end{array}$ & - & 13,83 & 43,33 & 7,69 & 17,39 & 20,56 \\
\hline 4 & $\begin{array}{l}\text { Günübirlik } \\
\text { Çalışanlar }\end{array}$ & - & 11,70 & 46,67 & 7,69 & 15,22 & 20,32 \\
\hline 5 & Hiçbiri & - & 18,09 & 6,67 & 44,62 & 10,87 & 20,06 \\
\hline
\end{tabular}

Yasal mevzuata göre çalışanların iş sağlığı ve güvenliği eğitimleri; a) İşyerinde görevli iş güvenliği uzmanları ile işyeri hekimleri tarafından, b) İşçi, işveren ve kamu görevlileri kuruluşları 
veya bu kuruluşlarca kurulan eğitim vakıfları ve ortaklaşa oluşturdukları eğitim merkezleri, üniversiteler, kamu kurumlarının eğitim birimleri, kamu kurumu niteliğindeki meslek kuruluşları ile Bakanlıkça yetkilendirilmiş eğitim kurumları ve ortak sağlık ve güvenlik birimleri tarafından verilir [17].
Ankete katılanların \%10,76'sı çalıştıkları şantiyede iş güvenliği eğitimi verilmediğini belirtirken, yalnızca \%77,32'si mevzuata uygun olarak iş güvenliği uzmanı ya da işyeri hekimi tarafından iş güvenliği eğitimi verildiğini belirtmişlerdir (Çizelge 7).

Çizelge 7. Çalışanlara iş güvenliği eğitimini verenler

\begin{tabular}{|c|c|c|c|c|c|c|c|}
\hline $\begin{array}{c}\text { Sira } \\
\text { No }\end{array}$ & $\begin{array}{c}\text { Çalışanlara İSG } \\
\text { Eğitimini Kim } \\
\text { Verir }\end{array}$ & $\begin{array}{l}\text { İşçi, } \\
\text { Usta, } \\
\text { Formen } \\
(\%) \\
\end{array}$ & $\begin{array}{c}\text { Teknik } \\
\text { Personel } \\
\text { (\%) }\end{array}$ & $\begin{array}{c}\text { ÍSG } \\
\text { Denetim } \\
\text { Elemanları } \\
(\%) \\
\end{array}$ & $\begin{array}{c}\text { Yapı } \\
\text { Denetim } \\
\text { Elemanları } \\
(\%) \\
\end{array}$ & $\begin{array}{l}\text { Üst Düzey } \\
\text { Yönetici - } \\
\text { İşveren } \\
(\%) \\
\end{array}$ & $\begin{array}{c}\text { Genel } \\
\text { Ortalama } \\
(\%)\end{array}$ \\
\hline 1 & Verilmez & 12,23 & 9,18 & - & - & 10,87 & 10,76 \\
\hline 2 & İşyeri Hekimi & 2,62 & 4,08 & - & - & 4,35 & 3,68 \\
\hline 3 & Şantiye Şefi & 12,66 & 18,37 & - & - & 39,13 & 23,39 \\
\hline 4 & Saha Mühendisi & 10,48 & 11,22 & - & - & 19,57 & 13,76 \\
\hline 5 & İSG Uzman1 & 72,93 & 80,61 & - & - & 67,39 & 73,64 \\
\hline 6 & Formen & 4,80 & 6,12 & - & - & 4,35 & 5,09 \\
\hline
\end{tabular}

\section{6. İş Sağlığı ve Güvenliği Denetimleri}

İş güvenliği denetimlerinin yapılması genel olarak işveren, iş güvenliği uzmanı ve işveren vekili olarak şantiye şefinin sorumluluğunda düşünülmekte olup, yasal mevzuat bu konuda diğer teknik personellere sorumluluk yüklememektedir [15,20,21]. Çok tehlikeli sınıfta yer alan işyerlerinde (A) sınıfı belgeye sahip iş güvenliği uzmanları ile 01.01.2018 tarihine kadar (B) sınıfı belgeye sahip iş güvenliği uzmanı görevlendirilmesi mümkündür $[15,21]$.

Anket genel ortalamasına göre ISG denetimi yapanlar arasında \%44,94 oranla şantiye şefi, $\% 28,80$ oranla A veya B sınıfı iş güvenliği uzmanı ve $\% 21,34$ oranla saha mühendisi ön plana çıkmaktadır (Çizelge 8).

Çizelge 8. Çalıştıkları şantiyede iş güvenliği denetimini yapan kişiler

\begin{tabular}{|c|l|c|c|c|c|c|c|}
\hline $\begin{array}{c}\text { Sıra } \\
\text { No }\end{array}$ & $\begin{array}{c}\text { Şantiyede İSG } \\
\text { Denetimini Kim } \\
\text { Yapıyor? }\end{array}$ & $\begin{array}{c}\text { İşçi, } \\
\text { Usta, } \\
\text { Formen } \\
\mathbf{( \% )}\end{array}$ & $\begin{array}{c}\text { Teknik } \\
\text { Personel } \\
\mathbf{( \% )}\end{array}$ & $\begin{array}{c}\text { ISG } \\
\text { Denetim } \\
\text { Elemanları } \\
\mathbf{( \% )}\end{array}$ & $\begin{array}{c}\text { Yapı } \\
\text { Denetim } \\
\text { Elemanları } \\
\mathbf{( \% )}\end{array}$ & $\begin{array}{c}\text { Üst } \\
\text { DüzeyYönetici } \\
- \text { İveren } \\
\mathbf{( \% )}\end{array}$ & $\begin{array}{c}\text { Genel } \\
\text { Ortalama } \\
\mathbf{( \% )}\end{array}$ \\
\hline 1 & Şantiye Şefi & 28,14 & 38,78 & 50,00 & 53,62 & 54,17 & 44,94 \\
\hline 2 & Saha Mühendisi & 19,05 & 20,41 & 30,00 & 10,14 & 27,08 & 21,34 \\
\hline 3 & A Sınıfi Uzmanı & 21,65 & 26,53 & 20,00 & 14,49 & 2,08 & 16,95 \\
\hline 4 & B Sinıfi Uzmanı & 21,65 & 12,24 & 13,33 & 5,80 & 6,25 & 11,85 \\
\hline 5 & C Sinıfi Uzmanı & 21,65 & 26,53 & 53,33 & 5,80 & 37,50 & 28,96 \\
\hline 6 & Formen & 9,52 & 9,18 & 6,67 & 0,00 & 18,75 & 8,82 \\
\hline 7 & Proje Müdürü & 1,30 & 1,02 & 3,33 & 2,90 & 6,25 & 2,96 \\
\hline 8 & Patron & 6,06 & 2,04 & 3,33 & 1,45 & 8,33 & 4,24 \\
\hline 9 & Yap1 Denetçi & 9,09 & 7,14 & 13,33 & 44,93 & 14,58 & 17,82 \\
\hline 10 & Hiçbiri & 10,82 & 4,08 & 0,00 & 2,90 & 4,17 & 4,39 \\
\hline
\end{tabular}




\section{SONUÇ VE ÖNERİLER}

\subsection{Sonuçlar}

Anket çalışmalarından elde edilen verilerin; güncel yasal mevzuat ve literatürde yer alan çalışmalar göz önünde tutularak değerlendirilmesi sonucunda ulaşılan bulgular aşağıda başlıklar halinde listelenmiştir.

\subsubsection{Kişisel Koruyucu Donanım (KKD) Kullanımları}

Literatür bulgularına göre KKD kullanımı iş güvenliğine önem verilmesi olarak değerlendirilmekte ve KKD kullanmayan çalışanlar iş kazası geçirme yönünden en riskli grup olarak görülmektedir.

Yasal mevzuata göre; yapılacak risk değerlendirmesi ile kullanılacak KKD belirlenir ve işverenler ile alt işverenler dâhil tüm çalışanların işyerlerinde KKD kullanması zorunludur.

Ankete katılan çalışanların KKD kullanım oranları incelendiğinde, en düşük kullanım oranının yapı denetimi ve kontrol teşkilatı grubunda olduğu görülmektedir. Eğitim seviyesi yüksek olan yap1 denetim grubunda KKD kullanım oranının düşük olması şaşırtıcı olmakla birlikte, teknik personel ve üst düzey yönetici gruplarında ve en önemlisi iş güvenliği denetim elemanlarında bile, baret ve çelik burunlu ayakkabı gibi hemen hemen her koşulda zorunlu tutulan KKD kullanım oranı $\% 100$ değildir.

\subsubsection{Sağlık Raporları}

Yasal mevzuata göre inşaat sektöründe çalışacak olanların, işe başlamadan önce sağlık raporu almaları ve bu raporda yapacakları işe uygun olduklarının belirtilmesi gerekmektedir.

Yapılan anket çalışmasında sağlık raporunun $\% 68,57$ oranında işe başlamadan önce alındığ görülse de, birçok çalışanın bu raporu almadığ 1 ya da işbaşı sonrasında aldığ 1 tespit edilmiştir.

\subsubsection{Mesleki Yeterlilik Belgeleri}

Literatür bulgularına göre inşaat sektöründe çalışacakların iş güvenliği davranışının iyileştirilmesi için, merkezi bir organizasyona kayıtlı olması ve meslekleriyle ilgili iş güvenliği eğitimi almaları gereklidir.

Yasal mevzuata göre inşaat sektöründe yer alan işyerlerinde yetki belgeli usta çalıştırılması zorunludur.

Anket çalışmasına göre mesleki yeterlilik belgesi olmayan çalışan oranı \%68,99 seviyesindedir. Bu durum, inşaat sektöründe vasıfsız eleman istihdamı açısından da bir göstergedir.

\subsection{4. İş Güvenliği Eğitimleri}

Literatür bulgularına göre iş güvenliği eğitimi verilmesinin oranı arttıkça, iş kazası geçirme riski azalmaktadır. Ancak uygulamada iş güvenliği eğitimi verilme oranının çok düşük olduğu görülmektedir.

Anket sonuçlarına göre; ana firma çalışanlarına, taşeron çalışanlarına, 30 günden kısa süreli ve günlük çalışanlara iş güvenliği eğitiminin verilme oranı yetersiz olup, eğitiminin doğru zamanlarda verilmesi oranı da çok düşüktür.

Yapılan anket çalışmasına göre, iş güvenliği eğitimi çoğunlukla iş güvenliği uzmanı ya da işyeri hekimi tarafından verilse de, eğitimin hiç verilmemesi ya da yetkisiz personel tarafindan eğitim verilmesi oranı da az değildir.

\subsection{5. İş Güvenliği Denetimleri}

Literatürde yer alan çalışmalarda iş güvenliği denetimlerinin yeteri kadar yapılmadığı, iş güvenliği denetimi arttırılan şantiyelerde güvenlik indeksinin de arttığı görülmüştür.

Yapılan anket çalışmasında; çok tehlikeli sınıfta yer alan inşaat sektöründe hizmet verebilecek $A$ ve B sınıfı iş güvenliği uzmanlarının görev aldığı işyeri oranı \%28,80 olarak tespit edilmiştir. Elde 
edilen veriler, iş güvenliği denetimlerinin yetersiz olduğunu göstermektedir.

\section{2. Öneriler}

Türkiye'de iş sağlığı ve güvenliğin konusunda yasal düzenlemeler yapılmış olmakla birlikte, yasal mevzuatın inşaat sektöründe uygulanması ve uygulamanın yaygınlığı yetersizdir. Yasal mevzuatın etkin bir şekilde uygulanması ve inşaat sektöründe iş sağlığg ve güvenliğinin sağlanması için tüm paydaşlara aşağıdaki öneriler sunulmuştur.

İş sağlığg ve güvenliği konusunda toplumsal ve sektörel bilincin arttırılması ve özellikle KKD kullanımı ile ilgili çalışanların bilinçlendirilmesi gerekmektedir.

İş sağlığı ve güvenliği eğitimlerinin, yasal mevzuata uygun olarak; doğru zamanlarda, tüm çalışanlara ve yetkin kişiler tarafindan verilmesi konusunda işverenlere maddi destek sağlanması ya da teşvik verilmesi gerekmektedir.

Mesleki yeterlilik belgesine sahip çalışan istihdamı mutlaka sağlanmalıdır. Bu konuda uygulamanın yayılması için meslek odaları, İş ve İşçi Bulma Kurumu, Milli Eğitim Bakanlığı ve üniversitelerle işbirliği yapılmalıdır.

Çalışma Bakanlığı tarafından yeterli sıklıkta iş sağlığı ve güvenliği denetimlerinin yapılması ve yasal mevzuata göre işverenin mevcut sorumlulukları azaltılmaksızın, yap1 denetim firması ve çalışanlarının iş sağlığı ve güvenliği konusundaki sorumlulukları arttırılmalıdır. İş sağlığı ve güvenliği denetimi; sorumlulukları arttırılmış yapı denetim firması, iş sağlığ ve güvenliği denetim personeli, teknik personel ve yöneticiler tarafindan ayrı ayrı takip edilmelidir.

Sektördeki tüm çalışanların; öncelikle aldıkları iş sağlığı ve güvenliği eğitimleri ve mesleki yeterliliklerinin takibi olmak üzere, haklarındaki tüm bilgilerin saklanması ve takibi için genel bir bilgi takip sistemi kurulmalıdır.
İş sağlığ1 ve güvenliği denetim personelinin daha etkin görev yapabilmeleri için; çalışan sayısına bağlı olarak aylık belirli sürede A sınıfı iş güvenliği uzmanı bulundurulmasına ilave olarak, tam zamanlı ara eleman istihdamı sağlanmalıdır.

Yapım işlerinde çalışan beş farklı meslek grubunu kapsayan bu çalışma, elde edilen genel sonuçlarla birlikte ileriki çalışmalar için yön gösterici olabilir. İş sağlığı ve güvenliği ile ilgili kanun ve yönetmeliklerin, inşaat sektörü üzerindeki etkilerini ve inşaat sektöründe uygulama oranının zaman içindeki değişimini tespit etmek için yapılacak araştırmalarda bu çalışmadan elde edilen sonuçlar kullanılabilir.

\section{KAYNAKLAR}

1. Dorji, K., Hadikusomo, B.H.W., 2006. Safety Management Practices in the Bhutanese Construction Industry, Journal of Construction in Developing Countries, 11(2), 53-75.

2. Kuruoğlu, Y., Kuruoğlu, M., Bask1, H.G., Müngen, M.U., 2007. Fiziksel Güce Dayalı İnşaat İşlerinde Çalışanların İş Yaşamı, İş Sağlığı ve Güvenliğine Bağlı Performanslarının Değerlendirilmesi, İş Sağlığı ve Güvenliği Sempozyumu, Ankara.

3. Demirbilek, T., Çakır, Ö., 2008. Kişisel Koruyucu Donanım Kullanımını Etkileyen Bireysel ve Örgütsel Değişkenler, Dokuz Eylül Üniversitesi İktisadi ve İdari Bilimler Fakültesi Dergisi, 23(2), 173-191.

4. Lam, C.S., Kam, Y.K., 2000. Safety Training to Improve Construction Worker Behaviour, 6th Annual Conference of the Australia and New Zeland Assocation of Occupational Health and Safety Education, Sydney /Australia.

5. Hassanein, A.A.G., Hanna, R.S., 2008. Safety Performance in the Egyptian Construction Industry, Journal of Construction Engineering and Management, June, 451-455.

6. Cheng, C.W., Leu, S.S., Lin, C.C., Fan, C., 2010. Characteristic Analysis of Occupational Accidents at Small Construction Enterprises, Safety Science, 48, 698-707.

7. Metinsoy, T., Müngen, U., 2011. İnşaat Sektöründe İş Güvenliği Yönetimi ve Genel İş 
Güvenliği Performansı İlişkisinin Değerlendirilmesi Yöntemi, 3. İşçi Sağlığı ve İş Güvenliği Sempozyumu, Çanakkale.

8. Dikmen, S.Ü., Tüzer, F.S., Yiğit, S., 2011. 4857 Sayılı Yasa ve İnşaat Şantiyelerinde İş Sağlığ1 ve Güvenliği Yaklaşımları, Türkiye Mühendislik Haberleri, 469(5), 25-31.

9. Antmen, B., Çelik, G., Tantekin, Oral, E.L., 2013. Şantiye Şefliği Kapsamında İş Sağlığı ve Güvenliği Uygulamaları, 4. İşçi Sağlığı ve İş Güvenliği Sempozyumu, Konya.

10. Laitinen, H., Ruohomaki, I., 1996. The Effects of Feedback and Goal Setting on Safety Performance at Two Construction Sites, Safety Science, 24(1), 61-73.

11. İş Sağlığı ve Güvenliği Yönetmeliği, Resmi Gazete Tarih: 09.12.2003, Say1:25311.

12. İş Sağlığı ve Güvenliği Hizmetleri Yönetmeliği, Resmi Gazete Tarih: 29.12.2012, Say1:28512.

13. Kişisel Koruyucu Donanımların İşyerlerinde Kullanılması Hakkında Yönetmelik, Resmi Gazete Tarih: 02.07.2013, Sayı:28695.

14. Yap1 İşlerinde İş Sağlığı ve Güvenliği Yönetmeliği, Resmi Gazete Tarih:05.10.2013, Say1:28786.

15. 6331 sayılı İş Sağlığı ve Güvenliği Kanunu, Resmi Gazete Tarih: 30.06.2012, Say1:28339.

16. 3194 sayılı İmar Kanunu, Resmi Gazete Tarih: 09.05.1985, Say1:18749.

17. Çalışanların İş Sağlığı ve Güvenliği Eğitimlerinin Usul ve Esasları Hakkında Yönetmelik, Resmi Gazete Tarih: 15.05.2013, Say1:28648.

18.4857 sayılı İş Kanunu, Resmi Gazete Tarih: 10.06.2003, Say1:25134.

19. Geçici veya Belirli Süreli İşlerde İş Sağlığı ve Güvenliği Hakkında Yönetmelik, Resmi Gazete Tarih: 23.08.2013, Sayı: 28744.

20. Yap1 Müteahhitlerinin Kayıtları ile Şantiye Şefleri ve Yetki Belgeli Ustalar Hakkında Yönetmelik, Resmi Gazete Tarih: 16.12.2010, Say1: 27787.

21. İş Güvenliği Uzmanlarının Görev, Yetki, Sorumluluk ve Eğitimleri Hakkında Yönetmelik, Resmi Gazete Tarih: 29.12.2012, Say1: 28512. 
